\title{
Surrater PENYULUHAN MENGGALI POTENSI TANAMAN OBAT PADA
SMAN 1 RAMBUTAN BANYUASIN SUMATERA SELATAN
}

\author{
Syaiful Eddy, Inka Dahlianah*, Syamsul Rizal, Trimin Kartika \\ Jurusan Biologi, Universitas PGRI Palembang \\ *Corresponding author: inkadahlianah rohim@gmail.com
}

\begin{abstract}
ABSTRAK
Pemanfaatkan tanaman obat sebagai pengobatan pada masyarakat merupakan warisan secara turun temurun. Sejalan dengan kemajuan teknologi dan informasi akan obat modern, maka penggunaan tanaman obat mengalami penurunan. Penurunan pengetahuan tentang tanaman obat terutama dialami oleh anak-anak sekolah sebagai generasi muda. Permasalahan mitra SMAN 1 Rambutan adalah ketidak tahuan dan rendahnya pengetahuan mereka akan tanaman obat dan potensi yang ada pada tanaman obat. Materi penyuluhan meliputi manfaat dan kegunaan tanaman obat, potensi tanaman obat sebagai tanaman hias, manfaat daun kelor (Moringga olifera) sebagai tanaman obat dan tanaman obat bernilai ekonomi. Metode pengabdian kepada masyarakat menggunakan metode ceramah, diskusi dan tanya jawab yang bersifat interaktif melalui dua arah. Bentuk transfer ilmu tidak hanya sosialisasi namun juga praktik. Hasil dari kegiatan pengabdian kepada masyarakat ini, bagi peserta yaitu siswa SMA N 1 Rambutan mengalami peningkatan pengetahuan tentang potensi tanaman obat kira-kira $95 \%$.
\end{abstract}

Kata Kunci: Tanaman obat, Tanaman hias, Potensi tanaman obat.

\section{PENDAHULUAN}

Tanaman obat adalah tumbuhan yang berkhasiat obat yaitu dapat mencegah, mengobati dan menyembuhkan penyakit bagi manusia. Tanaman obat yang ditanaman dipekarangan sekolah dapat berfungsi sebagai tanaman hias. Tanaman obat sebagai tanaman hias dapat dilihat dari morfologi daun, batang, buah,bunga yang memberi keindahan bagi pekarangan sekolah. Pemanfaatan tanaman sebagai obat-obatan juga telah berlangsung ribuan tahun yang lalu, namun penggunaannya belum terdomestikasi dengan baik (Widjaya et al, 2014). Lebih lanjut menurut Susiarti, (2015), tradisi pengobatan dapat ditelusuri kembali lebih dari lima milenia yang silam dengan munculnya dokumen tertulis dari peradaman kuno cina, India dan Timur Tengah. Obat

adalah suatu bahan atau panduan bahanbahan yang dimaksudkan untuk digunakan dalam penetapan diagnosa mencegah, menghilangkan, menyembuhkan penyakit atau gejala penyakit luka atau kelainan badaniah atau rohaniah pada manusia atau hewan-hewan untuk memperoleh kesehatan tubuh atau bagian tubuh manusia. Tanaman obat sudah banyak sekali digunakan oleh manusia sejak zaman dahulu, bahkan di percaya memiliki khasiat yang lebih ampuh daripada obat kimia. Pemanfaatan tanaman obat sebenarnya adalah untuk memenuhi bagi kehidupan, termasuk keperluan untuk mengatasi kesehatan secara tradisional, kenyataan menunjukkan bahwa obat yang berasal dari 
sumber bahan alami khususnya tanaman obat telah memperlihatkan peranannya dalam penyelenggaraan upaya kesehatan masyarakat. Menurut Tukiman, (2004), pemanfaatan tanaman obat keluarga yang digunakan untuk pengobatan gangguan kesehatan keluarga menurut gejala umum seperti demam panas, batuk, sakit perut dan gatal-gatal. Contoh pengobatan secara tradisional misalnya batuk, tanaman obat yang digunakan adalah tanaman obat jeruk nipis, obat gatal-gatal dengan menggunakan kunyit dan tanaman obat lain sebagai pengobatan secara alami atau tradisional. Menurut WHO, lebih dari 20.000 spesies tumbuhan berkhasiat obat digunakan oleh penduduk di seluruh dunia (Arsyah, 2014). Keuntungan obat tradisional yang langsung dirasakan oleh masyarakat adalah kemudahan untuk memperoleh bahan bakunya dapat ditaman di pekarangan rumah.. WHO memperkirakan bahwa 80 persen warga di benua Asia dan Afrika memanfaatkan pengobatan herbal untuk beberapa aspek perawatan kesehatan. Banyak obat-obatan modern yang menggunakan tanaman obat sebagai bahan baku pembuatan obat (Kintoko, 2006). Lebih lanjut menurut Williams, (2006), bahwa tanaman oregano, basil, thyme dan tanaman herbal lain merupakan sumber aktioksidan yang sangat baik. Tanaman obat yang biasa di tanam di pekarangan rumah adalah jahe, lidah buaya, beluntas, kunyit, kemangi, daun ungu, kenop, kencur, belimbing wuluh, daun dewa, cabe, sirih, serai, bunga pukul empat, temulawak, kenikir. Pengobatan dengan menggunakan tanaman sebagai bahan bakunya disebut juga sebagai pengobatan tradisional. Tingginya minat masyarakat menggunakan tanaman obat untuk kesehatan, karena mereka beranggapan lebih aman tidak ada dampak negatifnya bila menggunakan obat tradisional berbahan baku tumbuhan, kenyataannya obat tradisional dari tumbuhan bisa terkontaminasi. Menurut Hartati, (2012), bahwa secara umum, kontaminan pada tumbuhan obat bisa dibagi ke dalam 5 kelompok, yaitu kontaminan biologis, kimia (mikotoksin, logam dan logam berat, dan residu pestisida), radioaktif dan pemalsuan bahan obat dan kontaminan dari luar yaitu tumbuhan mengandung racun. Tanaman yang digunakan sebagai bahan baku sebagai obat dapat berfungsi sebagai tanaman hias. Contoh tanaman obat yang dapat berfungsi sebagai tanaman hias yaitu lidah buaya(Aloe vera), tanaman kenop (Gomphrena globosa), bunga pukul empat (Mirabilis jalapa), cocor bebek (Kalanchoe pinnata Syn), beluntas (Pluchea indica) yang dapat dijadikan sebagai tanaman pagar, dan masih banyak lagi tanaman obat yang berfungsi ganda sebagai tanaman hias. Potensi tanaman obat dan potensi tanaman obat sebagai tanaman hias dapat dijadikan peluang usaha untuk meningkatkan perekonomian, baik untuk skala kecil atau sebagai komoditas ekspor. Fungsi lain tanaman obat sabagai tanaman hias tidak hanya dilihat dari daun, batang, bunga, akan tetapi aroma wangi (aromatik) dari tanaman obat tersebut. Bau wangi (aromatik) ini disebabkan adanya kandungan minyak atsiri (Utami, 2006). Analisis situasi permasalahan yang dihadapi sekolah SMAN 1 rambutan sebagai peserta mitra yaitu rendahnya pengetahuan tentang potensi dari tanaman obat, yang tidak saja peruntukan sebagai obat juga berfungsi untuk menunjang keindahan pekarangan sekolah sebagai tanaman hias, melalui analisis situasi maka peserta mitra masih memerlukan peningkatan pengetahuan mengenai potensi dari tanaman obat. Pengetahuan diberikan secara teori maupun praktek untuk membawa perubahan pola pikir siswa untuk memanfatkan pekarangan sekolah sebagai penunjang kesehatan, dan keindahan lingkungan sekolah melalui kegiatan secara produktif dan berkesinambungan.

\section{METODE KEGIATAN}

Adapun metode yang di gunakan dalam pengabdian kepada masyarakat di SMA Negeri 1 rambutan adalah metode ceramah termasuk penayangan materi dengan 
metode ceramah, demonstrasi dan praktik dengan metode memperlihatkan tanaman obat, pemanfaatan tanaman obat, pembuatan obat dari tanaman obat, memperlihatkan jenis tanaman obat sebagai tanaman hias melalui morfologi tanaman, dan memperkenalkan tanaman obat yang berlilai ekonomi, dilanjutkan dengan diskusi dan tanya jawab. Metode ceramah yang dilaksanakan dalam penyuluhan ini sebagai pemateri pertama yaitu memberikan penjelasan tentang tanaman obat, yaitu bagian mana dari tanaman yang berfungsi sebagai obat, bagaimana caranya membuat obat, bagaimana cara mengaplikasi tanaman obat, dan mempraktikkan cara pembuatan obat dengan bahan baku tanaman obat, dilanjutkan dengan diskusi dan tanya jawab, pemateri kedua yaitu memberikan penjelasan tanaman obat sebagai tanaman hias, bagian mana dari morfologi tanaman obat yang memiliki nilai estetika tinggi, tanaman mana yang bisa dibentuk pergola, tanaman pagar, sebagai contoh tanaman beluntas bisa dijadikan tanaman hias untuk diluar ruangan sebagai pagar tanaman, dan tanaman obat sebagai tanaman hias ini berpotensi juga sebagai agrowisata edukasi yang memiliki nilai jual yang tinggi dilanjutkan dengan demonstrasi dan dilanjutkan dengan diskusi serta tanya jawab, materi ketiga dan ke empat melaksanakan demostrasi, diskusi dan dilanjutkan dengan tanya jawab, pemateri ketiga memberikan penjelasan tentang tanaman kelor yaitu manfaat dan fungsi tanaman kelor yang diperuntukkan sebagai tanaman obat, dan pemateri terakhir atau keempat yaitu memberikan penjelasan bahwa tanaman obat dapat memiliki nilai ekonomi tinggi bila ditingkatkan nilai ekonominya, seperti diolah sebagai minuman dengan dikemas sedemikian rupa, dibuat kapsul dan sebagainya dan dapat memberikan masukan atau income bagi peserta kegiatan pengabdian kepada masyarakat. Kegiatan terakhir adalah memberikan kuisioner untuk melihat pemahaman para peserta dalam mengikuti kegiatan pengabdian kepada masyarakat.

\section{HASIL DAN PEMBAHASAN}

Pelaksanaan penyuluhan ini dilakukan oleh tim dosen Biologi Fakultas MIPA Universitas PGRI Palembang pada tanggal 6 Maret 2018, penyuluhan terdiri dari 4 sesi. Sesi pertama ceramah memberi penjelasan tentang materi masing-masing penyuluh, sesi kedua demonstrasi, sesi ketiga praktik, dan terakhir diskusi dan tanya jawab. Adapun peserta pengabdian kepada masyarakat adalah siswa kelas XII SMAN 1 Rambutan Kabupaten Banyuasin sumatera selatan. Materi yang diberikan pada penyuluhan ini terdiri dari 4 sesi. Materi yang diberikan yaitu:

1. Manfaat dan kegunaan tanaman obat

2. Potensi Tanaman obat sebagai tanaman hias

3. Manfaat daun kelor (Moringga Olifera) sebagai tanaman obat

4. Tanaman obat bernilai ekonomi.

Kegiatan pengabdian ini dimulai dengan memberikan penyuluhan, demontrasi, dan praktik. Materi pertama yaitu manfaat dan kegunaan tanaman obat, sebagai pembuka kegiatan, pada kesempatan pertama ini penyuluh memperkenalkan jenis-jenis tanaman obat, dengan menunjukkan jenisjenis tanaman obat yang dibawa oleh tim penyuluh, tim penyuluh berinteraksi dengan siswa mengenai tanaman obat, sebagian besar siswa mengetahui nama daerah dari tanaman obat akan tetapi belum memahami betul nama ilmiah, manfaat dan cara membuat obat dari bahan baku tanaman obat dan aplikasi tanaman obat untuk pengobatan pada penyakit. Pada materi kedua, memperkenalkan tanaman obat sebagai tanaman hias, sebagai penghias di halaman sekolah, halaman perkantoran, tanaman penghias jalan, dan taman- taman hias, dan menjelaskan bahwa tanaman obat memiliki potensi lain yaitu sebagai tanaman hias sebagian besar peserta belum mengetahui bahwa tanaman obat bisa berfungsi sebagai tanaman hias. Penyuluh memberikan contoh misalnya pada tanaman lidah buaya, tanaman pukul 
empat, tanaman kenop, penyuluh juga menjelaskan morfologi tanaman tersebut yang mana bernilai estetika tinggi, dan terakhir memberikan penjelasan dampak bagi kesehatan dari lingkungan yang dipenuhi dengan tanaman yang asri dan indah. Sesuai dengan pendapat, Kahairudin, Z (2015), bahwa tanaman obat untuk mempercantik lingkungan dan pekarangan diantaranya lidah buaya, yaitu tanaman obat yang paling banyak di tanam di pekaranagn, cocor bebek yaitu tanaman yang banyak mengandung air, tanaman obat ini terlihat sangat indah. Pada materi ketiga penyuluh memberikan penjelasan manfaat daun kelor sebagai tanaman obat dan juga menjelaskan kandungan zat kimia yang terdapat pada tanaman daun kelor dan untuk pengobatan apa saja daun kelor tersebut dan cara pengolahan dan aplikasinya sebagai obat. Penjelasan lebih rinci bahwa daun kelor memberikan manfaat untuk ibu-ibu menyususi, menurunkan gula darah, mengurangi keriput diwajah dan luka, obat alternatif untuk penyakit kanker, obat sakit kepala, meningkatkan hemoglobin darah, meningkatkan hormon dopamin, meningkatkan daya ingat, penyakit jantung, dan menurunkan tekanan darah. Peserta hanya tahu bahwa daun kelor itu berhubungan dengan mistik.

Pada materi keempat, yaitu tanaman obat bernilai ekonomis, disini penyuluh menjelaskan tanaman obat yang bernilai ekonomi, penyuluh memberikan contoh misalnya pada tanaman lidah buaya selain sebagai obat, dapat memberikan manfaat lain berupa produk olahan lidah buaya berupa produk makanan, minuman, dan kecantikan. Produk makanan dan minuman berupa, nata de aloe, syirup, dodol, kripik dan lain-lain, serta produk kecantikan berupa cream wajah, kulit, dan shampo untuk rambut. Antusias peserta begitu tinggi mendengarkan penyuluhan dan praktik pembuatan obat dari bahan baku tanaman obat, dari empat penyuluh, respon peserta diperlihatkan dengan memberikan pertanyaan kepada ke empat penyuluh, pertanyaan seperti seberapa jauh khasiat dari tanaman obat dan peserta meminta penjelasan secara detail akan fungsi dari masing-masing tanaman yang berkhasiat obat yang dibawa penyuluh, kemudian peserta juga meminta penjelasan tanaman obat apa saja yang memiliki nilai estetika tinggi, pertanyaan selanjutnya mengenai tanaman daun kelor yang selama ini tanaman daun kelor berkaitan erat dengan dunia mistis, terakhir pertanyaan peserta seberapa besar nilai ekonomi dari masingmasing tanaman obat yang dibawa penyuluh. Kegiatan pengabdian ini merupakan kegiatan yang menimpbulkan dampak yang sangat baik, terlihat dari diskusi kedua belah pihak antara penyuluh dan peserta sangat interaktif. Kegiatan penyuluhan ini berhubungan erat dengan program sekolah yaitu program adiwiyata yang berhubungan dengan pemanfatan tanaman obat di pekarangan sekolah dan keindahan lingkungan. Penyuluhan seperti ini dapat memberi manfaat yang cukup besar yaitu memberikan pengetahuan bahwa pengobatan dengan obat-obatan tradisional berperan dalam menunjang kesehatan masyarakat, selain itu tanaman obat sebagai tanaman hias dapat lebih meningkatkan nilai ekonomi dari tanaman obat tersebut. Manfaat utama penyuluhan ini dapat memanfatkan secara efisien halaman atau pekarangan sekolah. Menciptakan lingkungan yang indah dan arsi sehingga dapat menunjang kegiatan belajar dan mengajar di sekolah yang lebih baik. Selanjutnya kegiatan penyuluhan seharusnya diberikan materi tentang budidaya tanaman obat tersebut, agar mendapatkan hasil yang maksimal. Pada waktu kegiatan praktik peserta sangat antusias untuk mencoba dan mempraktikkan pembuatan obat dari bahan baku tanaman Faktor keberhasilan penyuluhan pada peserta harus diiringi dengan tingkat usia, pendidikan, informasi yang diperoleh, sesuai dengan pendapat Sari, I.D, dkk, (2015), bahwa faktor yang mempengaruhi penggunaan tanaman obat yaitu pengalaman pribadi, usia, pendidikan, informasi dari luar, pendapatan serta faktor 
sosial dan budaya. Faktor jarak ke pusat kota juga mempengaruhi, karena kecamatan banyuasin , rambutan jauh dari pusat kota palembang.

\section{PENUTUP}

Adapun kesimpulan dari kegiatan pengabdian kepada masyarakat ini adalah:

Peserta pengabdian pada masyarakat ini sangat antusias dan responsif dalam menyimak dan menanggapi yang dijelaskan penyuluh maupun pada saat demosntrasi, dan praktik serta tanya jawab. Kegiatan penyuluhan dalam program pengabdian kepada masyarakat ini berjalan tertib dan lancar. Peserta mitra siswa SMA N 1 mengalami peningkatan pengetahuan mengenai potensi tanaman obat kira-kira 95\%. Saran pengabdian selanjutnaya yaitu mengenai budidaya tanaman obat.

\section{DAFTAR PUSTAKA}

Arsyah, C. Disca. 2014. Kajian Etno Botani Tanaman Obat Herbal dan pemanfatannya dalam Usaha Menunjang Kesehatan Keluarga. Di Dusun Turgo, Purwobinangun, Pakem, Sleman. Skripsi. Fakultas Sains dan Teknologi. Universitas Islam Negeri Sunan Kalijaga Yogya, Yogyakarta.

Hartati, D. 2012. Kontaminasi pada Obat Herbal. Jurnal Pharmacy, Vol.0.9 No.0.3 Desember 2012. ISSN 1693 - 3591

Kahairudin, Zamroni. 2015. Dalam artikel Satu Jam: Mempercantik Pekaranagn Rumahdengan Tanaman Obat. Http://www.satu jam.com/mempercantikpekarangan-rumah-dengantanaman-obat/

Kintoko, 2006. Potensi pengembangan tanaman obat. Fakultas Sains dan
Teknologi.Universitas Kebangsaan Malaysia. Prosiding Persidangan Antar Bangsa Pembangunan Aceh.

Sari.I.D, Yuyun Y, Selma S, Riswati, Muhammad S, 2015. Tradisi Masyarakat dalam Penanaman dan pemanfaatan tumbuhan Obat Lekat di Pekarangan. Jurnal Kefarmasian Indonesia. Vol.5. No. 2. Agustus 2015. p-ISSN: 2085-675X, eISSN:2354-8770.

Susiarti, S. 2015. Pengetahuan dan Pemanfaatan TumbuhanObat Masyarakat Lokal di Pulau Seram, Maluku Bidang Botani, Pusat Penelitian Biologi, Lembaga Ilmu Pengetahuan Indonesia Bogor.

Tukiman. 2004. Pemanfaatan Tanaman Obat Keluarga (TOGA) untuk kesehatan Keluarga. 2004 Digitized bu USU Digital Library.

Utami, Rai I Gusti. 2006. Potensi pengembangan agrowisata di Indonesia. Http://potensi bgn//artikel. Diakses tanggal 1 Januari 2018.

Widjaya, E.A, Rahayuningsih, Y, Rahajoe, J.S, Ubaidillah, R. Maryanto, I, Walujo, E.B, Semiadi. 2014. Kekinian Keanekaragaman Hayati Ind. LIPI Press, Kementrian Lingkungan Hidup \& Bappenas.

Williams, P.G. 2006. Health benefits of herbsand spices: the past, the present, the future-Public Health. Medical Journal of Australia.Faculty of Health and Behavioural Sciences-Papers. Faculty of Science, Medicine and Health. University of Wollongong. Australia.Reseach Online. 